\title{
PENGEMBANGAN IMAJINASI KREATIF BERBASIS NEUROSAINS DALAM PEMBELAJARAN KEAGAMAAN ISLAM
}

\author{
Desfa Yusmaliana \\ Universitas Ahmad Dahlan, Yogyakarta, Indonesia \\ yusmaliana.desfa@yahoo.co.id \\ Suyadi \\ Universitas Ahmad Dahlan, Yogyakarta, Indonesia \\ suyadi@fai.uad.ac.id
}

\begin{abstract}
This article aims to develop students' creative imagination based on neuroscience in the process of Islamic religious learning. This study was library research with a qualitative approach by using the Haberman and Miles model. All children's aspects when they are golden age develop very rapidly so the optimal stimulation is required. One of them is the development of creative imagination. The creative imaginations have not been developed much, even it is considered as learning disruptions. However, in the path of history, many scientists put forward their creative imagination in their childhood. It shows that creative imagination is not a learning disorder but a technique to optimize brain function more optimal. Learning activities that stimulate children's creative imagination such as playing religious music, reading grand stories, spiritual songs, aesthetic dances and unique paintings are very important to be developed in the Islamic learning process.
\end{abstract}

Keywords: creative imagination, neuroscience, Islamic religious learning 


\begin{abstract}
Abstrak
Artikel ini bertujuan untuk mengembangkan imajinasi kreatif peserta didik berbasis neurosain dalam proses pembelajaran keagamaan Islam. Penelitian ini merupakan penelitian kepustakaan dengan pendekatan kualitatif model Haberman dan Miles. Dalam periode keemasan anak, seluruh aspek berkembangan sangat pesat sehingga diperlukan stimulasi yang optimal, salah satunya dengan pengembangan imajinasi kreatif. Selama ini imajinasi kreatif belum banyak dikembangkan bahkan dianggap sebagai ganguan belajar. Tetapi, dalam lintasan sejarah banyak ilmuwan yang di masa anak-anak mengedepankan imajinasi kretifnya. Hal ini menunjukkan bahwa imajinasi kreatif bukan ganguan pembelajaran melainkan teknik optimalisasi fungsi otak lebih maksimal. Kegiatan-kegiatan pembelajaran yang menstimulasi imajinasi kreatif anak seperti bermain musik religi, pembacaan kisahkisah agung, nyanyian-nyanyian spiritual, tarian-tarian estetik, lukisanlukisan unik, dan lain-lain sangat penting dikembangkan dalam proses pembelajaran keagamaan Islam.
\end{abstract}

Kata kunci: imajinasi kreatif, neurosains Pendidikan, dan pembelajaran keagamaan Islam

\title{
A. Pendahuluan
}

Pendidikan adalah upaya sadar dalam mengembangkan potensi-potensi yang ada pada peserta didik secara maksimal. Sistem pendidikan dapat mengubah, mengarahkan atau bahkan membentuk manusia sesuai dengan tahap perkembangannya. G. Thompson mengungkapkan bahwa pendidikan merupakan dampak lingkungan terhadap individu dalam menghasilkan perubahan dalam bentuk kebiasaan, pemikiran, sikap dan tingkah laku. Demikian pula Crow sependapat bahwa fungsi utama dari pendidikan adalah membimbing individu dalam memenuhi kebutuhan serta keinginannya yang sesuai dengan potensi-potensi yang dimilikinya (Taufiq, Prianto, \& Mikarsa $2014,1.3)$. Dengan demikian, proses pendidikan jelas memiliki tugas dalam membangkitkan potensi dari masing-masing individu. Namun, permasalahannya adalah proses pengembangan atas kemampuan otak yang dimiliki oleh peserta didik tersebut seringkali terkesan sangat monoton dan tidak menarik. Pengembangan kreativitas berpikir di dalam kelas melalui imajinasi dan emosi dianggap aneh dan jauh dari 
pesan kognitif yang harus disampaikan. Lebih dari itu, anak-anak yang suka berimajinasi malah dianggap sebagai anak yang memiliki 'kelainan' dan tidak dianggap 'pintar' secara kognitifnya.

Menurut Egan, K., Stout, M., \& Takaya, K, masalah di atas disebabkan oleh karena imajinasi seringkali dianggap rendah dan bertentangan dengan akal (Davey 2009, 124). Lebih lanjut, masih adanya anggapan bahwa imajinasi hanya cocok dan semestinya ditempatkan pada pembelajaran seni dan sastra saja, sedangkan mata pelajaran agama Islam tidak. (Egan \& Judson 2016, 3), Dengan demikian penyebab tidak berkembangannya imajinasi kreatif dalam pembelajaran agama Islam adalah karena anggapan guru yang masih belum benar sehingga sistem pembelajaran masih terus monoton dan hanya sebatas pengembangan aspek kognitif semata, sedangkan pendidikan Islam secara filosofis memiliki hakekat membentuk insan kamil yang seimbang antara kognitif, afektif dan psikomotoriknya, dalam istilah psikologis disebut sebagai pengoptimalan potensi manusia (Suyadi 2012, 124). Menurut Judson terdapat dua poin utama dalam imajinasi, yaitu: 1) imajinasi berperan dalam semua pembelajaran, semua orang, bahkan semua tempat, dan 2) pendidikan merupakan wadah kognitif yang dapat digunakan sebagai alat dalam melejitkan imajinasi untuk memahami dunia (Judson, 2016).

Penemuan tentang gelombang otak dan fungsinya pada akhir 1960-an diiringi dengan penelitian-penelitian selanjutnya telah membawa paradigma baru dalam pengoptimalan fungsi otak. Penemuan bahwa fakta historis telah membenarkan banyak dari para jenius yang menggunakan kedua belahan kapasitas otak mereka secara simultan dapat menghasilkan karya besar. Tidak hanya pada belahan yang dianggap aktif secara nalar dan logika saja namun juga bagian lainnya yang berkaitan dengan irama, gambar dan imajinasi. Hal ini juga dibuktikan oleh penelitian lainnya yang menunjukkan bahwa jika seseorang berkeinginan mengembangkan bagian lain yang dianggap lemah, maka perkembangn tersebut tidak akan mengurangi wilayah lain, tetapi lebih menghasilkan pengaruh sinergis dimana seluruh bagian kinerja akan semakin meningkat (Buzan 2003, 12). Imajinasi bahkan merupakan alat terbaik dalam merangsang keefektifan dalam proses pembelajaran. Olah karena itu keterlibatan imajinasi harus ada pada setiap area mata pelajaran dalam meningkatkan dan membuat 
seluruh proses pembelajaran dan pengajaran menjadi efektif (Egan \& Judson 2016, 4) termasuk dalam pendidikan Islam yang memiliki tugas yang sangat luas dalam membimbing, membina, mengarahkan, serta memberdayakan seluruh potensi yang dimiliki otak secara anatomisnya yaitu kecerdasan intelektual, emosional, dan spiritual (Pasiak 2005, 18) dalam diri manusia agar mampu menghadapi problema kehidupan yang dihadapi berdasarkan Al-Quran dan As- Sunnah.

Dalam artikel ini penulis sependapat bahwa penerapan imajinasi kreatif pada setiap kelas dan setiap mata pelajaran harus segera dilaksanakan. Sehingga anggapan bahwa imajinasi cenderung dinilai tidak berarti dalam proses pendidikan telah terbantahkan oleh berbagai penelitian dan justru mengungkapkan sebaliknya. Untuk itulah dalam artikel ini, penulis akan mengulas lebih dalam tentang imajinasi kreatif dalam pembelajaran keagamaan Islam. Adapun jenis artikel ini merupakan penelitian telaah kepustakaan pendekatan kualitatif model Haberman dan Miles. Literaturliteratur yang berkaitan dengan tema imajinasi kreatif, sistem kerja otak dan pendidikan Islam digunakan sebagai bahan kajian yang diharapkan dapat memberikan gambaran yang jelas terhadap proses pengembangan imajinasi pada anak untuk memunculkan kreativitaskreativitas yang dapat mengoptimalisasikan perkembangan otak pada anak.

\section{B. Pembahasan}

\section{Imajinasi Kreatif}

"Imagination is more important than knowledge. For knowledge is limited to all we now know and understand, while imagination embraces the entire world, and all there ever will be to know and understand" Albert Einstein (Goodreads, n.d.), (Murrel 2001, 92). Seorang Albert Einstein telah mengemukakan bahwa imajinasi merupakan hal yang luar biasa terdapat dalam diri manusia. Ia memandang imajinasi adalah di atas ilmu pengetahuan. Hal ini dijelaskannya karena ilmu pengetahuan yang dimiliki oleh manusia akan terbatas pada masa dan pemahaman manusia pada saat dimana ia hidup dan berkreasi, namun dengan imajinasi yang dimiliki oleh manusia, manusia dapat membayangkan jauh kedepan bahkan berabad-abad setelah masanya 
di dunia. Sebagai contoh, dengan imajinasi seorang Bill Gates dan Steve Jobs, dapat membayangkan bahwa suatu hari nanti di setiap rumah akan terdapat komputer. Hal tersebut telah terjadi pada saat ini dan belum terbayangkan oleh kebanyakan orang pada masa tersebut.

Einstein telah berimajinasi bahwa dirinya dapat menembus waktu dan mengendarai cahaya sehingga memberi motivasi lebih baginya untuk terus berusaha dalam memecahkan misteri alam yang kemudian terbukti telah memberikan pondasi bagi perkembangan ilmu pengetahuan selanjutnya (Faisal 2015, 12). Einstein pun mengakui bahwa pandangan ilmiahnya yang lebih signifikan diperoleh karena imajinasinya. Bilangan, bentuk persamaan, dan kata-kata yang dikemas dari imajinasi ini merupakan bentuk dari teori relativitas penggabungan suatu sintesis cortex kiri dan kanan (Buzan 2003, 14).

Oleh karena itu imajinasi dapat dikatakan sebagai pemberi kontribusi terbesar bagi inovasi-inovasi di seluruh dunia di masa ini dan masa depan. Vygotsky percaya bahwa imajinasi merupakan dasar dari semua aktivitas kreatif, komponen penting dari semua aspek kehidupan budaya, memungkinkan penciptaan artistik, ilmiah, dan teknis dari seluruh dunia budaya manusia, yang berbeda dari dunia alam, semua ini adalah hasil imajinasi manusia dan ciptaan berdasarkan imajinasi (Fleer 2012, 34). Judson $(2014,10)$ menambahkan bahwa sesungguhnya manusia merupakan makhluk imajinatif yang melihat dan mempersepsikan, merasakan, dan memikirkan secara bersamaan sebagaimana David Kresch menyebutnya sebagai "perfinkers" atau lawan dari pemikir yang sederhana. Contohnya Einstein yang dulu pernah dianggap bodoh dan dikeluarkan dari kelas dengan nilai rapor selalu rendah ternyata bukanlah sebuah tolak ukur dari keberhasilannya (Pasiak 2005, 121). Ia lebih banyak menggunakan 'bayangan' yang kira-kira jelas agar dapat dengan 'sengaja' dibuat kembali dan digabungkan dalam menyelesaikan sebuah konsep (Atkinson, Atkinson, \& Hilgard 2011, 425)

Citra visual mungkin paling dikenal dalam pengembangan imajinasi ini karena efek langsungnya pada fisiologi. Melalui citra, manusia dapat menstimulasi perubahan dalam banyak fungsi tubuh yang biasanya dianggap tidak dapat diakses oleh pengaruh kesadaran. Citra visual akan memberikan interpretasi kepada manusia sendiri. Hal ini dikarenakan citra visual merupakan aliran pikiran yang bisa 
kita lihat, dengar, rasakan, cium, atau cicipi (Aschoeke et al. 2006, 73). Seperti yang diungkapkan di atas bahwa citra visual merupakan jendela di dunia batin manusia yang digunakan untuk melihat ide, perasaan, dan interpretasi manusia itu sendiri, karenanya citra visual juga merupakan sarana transformasi dan pembebasan dari distorsi di dunia ini yang tanpa sadar mengarahkan hidup manusia dan membentuk manusia.

Banyak orang percaya bahwa penalaran yang sangat erat kaitannya dengan ilmu pengetahuan adalah kegiatan yang berbeda dengan imajinasi. Tetapi, Bronowski (2015, 24) menyatakan sebaliknya dimana ia merunutkan kegiatan berimajinasi pada saat manusia masih kecil sampai dewasa. Ia mengatakan bahwa seorang anak mengeksplor segala sesuatu yang tampak disekelilingnya sebelum berusia satu tahun. Seorang bayi terus melihat objek yang dia lihat dan ini adalah langkah besar pertama dari perkembangan manusia dimana ketika tidak terlihat lagi menjadi tidak masuk akal baginya. Namun, dalam perkembangan beberapa tahun kemudian dalam hidupnya, seorang anak akan mengambil langkah kedua dan lebih besar yaitu membuat gambar dari hal yang tidak ada, dan mampu menggunakan gambar untuk berpikir tentang dirinya ke dalam situasi yang tidak diketahui. Pada saat itulah, seorang manusia memasuki pintu gerbang pemikiran imajinatif yang dalam hal ini termasuk proses pemikiran yang disebut bernalar.

Begitu pula dalam dunia pendidikan, imajinasi kreatif memiliki arti lebih dari sekedar berangan-angan atau berhayal. Kegiatan imajinasi kreatif adalah seperti yang dikatakan oleh Alan $\mathrm{R}$. White bahwa berimajinasi atau membayangkan adalah dengan menganggapnya sebagai kemungkinan dan orang yang imajinatif adalah orang yang memiliki kemampuan untuk memikirkan banyak kemungkinan, biasanya dengan beberapa detail yang banyak. Alan juga menambahkan bahwa imajinasi berkaitan dengan penemuan, penemuan dan orisinalitas karena pemikiran tentang kemungkinan daripada yang sebenarnya (Egan \& Judson 2016, 3).

Aktivitas-aktivitas dari imajinasi kreatif tergantung langsung pada kekayaan dan variasi pengalaman seseorang sebelumnya, karena pengalaman ini menyediakan bahan dari mana produk fantasi yang dibangun. Semakin kaya pengalaman seseorang, semakin kayalah 
bahan yang dapat diakses oleh imajinasinya. Dalam penelusuran sejarah karya-karya besar, penemuan-penemuan besar, maka hampir selalu dapat dipastikan bahwa hal tersebut merupakan hasil dari sebagian besar pengalaman yang sebelumnya telah terakumulasi dan setiap tindakan imajinasi dimulai dengan akumulasi pengalaman tersebut. Adapun setelah proses akumulasi pengalaman, Ribot mengatakan bahwa selanjutnya adalah masa inkubasi dimana periode ini akan berbeda-beda pada setiap individu. Newton membutuhkan waktu tujuh belas tahun dalam periode inkubasi ini ketika akhirnya mengkonfirmasi studinya dalam bentuk perhitungan. Ia kemudian mempercayakan orang lain untuk menyelesaikan perhitungan selanjutnya (Vygotsky 2004, 15).

Dari berbagai penjelasan di atas, maka sedikitnya terdapat empat komponen utama dari teori imajinasi kreatif sebagaimana diungkapkan oleh Smolucha (1986) dalam (Tsai 2012, 16), yaitu: 1) Imajinasi adalah internalisasi permainan anak-anak, 2) Imajinasi adalah fungsi mental yang lebih tinggi karena itu adalah proses berpikir yang diarahkan secara sadar, 3) Berpikir kreatif melibatkan kolaborasi imajinasi dan pemikiran dalam konsep, yang terjadi pertama kali pada masa remaja tetapi matang di masa dewasa, dan 4) Baik kreativitas artistik dan ilmiah membutuhkan kolaborasi imajinasi dan pemikiran dalam konsep.

Implikasi tersebut bagi pendidikan adalah, jika ingin membangun fondasi yang relatif kuat untuk kreativitas seorang anak, yang harus dilakukan adalah memperluas pengalaman dan rangsangan-rangsangan yang melibatkan imajinasi kreatif. Semakin banyak seorang anak melihat, mendengar, dan mengalami, semakin ia akan tahu dan berasimilasi, semakin banyak elemen realitas yang akan dimiliki dalam pengalamannya, maka semakin produktif imajinasinya. Oleh karena itu, kecenderungan dalam pendidikan dalam melihat imajinasi sebagai kategori yang berbeda, bahkan sampai taraf tertentu dikatakan sebagai ke'aneh'an bagi peserta didik yang sering berimajinasi merupakan pemikiran klasik yang sebenarnya tidak memiliki sisi kebenaran. Sebaliknya, imajinasi memiliki peranan yang sangat besar dalam mengembangkan potensi berpikir bagi seseorang sehingga menjadikannya bersifat kreatif. 


\section{Neurosains dan Pembelajaran Keagamaan Islam}

Perkembangan neurosains sebagai sebuah pengetahuan mengenai sistem syaraf atau tentang otak manusia saat ini mengalami kemajuan yang signifikan. Para pakar terus meneliti tentang hubungannya dengan kehidupan manusia termasuk dunia pendidikan dimana keunikan dari perkembangan kemampuan otak sangat terkait dengan output capaian dari sebuah proses pendidikan. Egan, Stout, and Takaya $(2007,12)$ menyatakan bahwa kemampuan otak tentu berbeda dari kemampuan yang ada pada komputer atau teknologiteknologi lainnya. Namun, sayangnya terkadang manusia malah berpikir seperti teknologi-teknologi tersebut dimana otak digunakan sebagai kotak penyimpanan semata. Padahal kenyataannya adalah otak belajar dengan campuran berbagai emosi, ingatan, niat, dan sebagainya yang membentuk kehidupan mentalnya. Untuk itulah, dalam proses pembelajaran, sebenarnya otaklah yang memasukkan informasi ke dalam wadah yang sebelumnya telah berisi informasiinformasi yang berkaitan sehingga membutuhkan restrukturisasi, penyusunan, dan penilaian kembali.

Dalam neurosains, sel syaraf otak atau neuron memiliki kemampuan yang luar biasa jauh dibandingkan dengan komputer yang hanya memiliki kapasitas tertentu dalam hal penyimpanan memori. Sharon Begley telah membuktikan bahwa sel syaraf otak mampu untuk meregenerasikan sel syaraf baru yang dikenal dengan neurogenesis. Sel syaraf tersebut juga mampu untuk beradaptasi dan melakukan perubahan sesuai dengan pengalaman yang diterima dari lingkungannya. Hal ini dikenal dengan istilah neuroplastisitas sel syaraf (Suadu 2018, 44). Keunikan dan kehebatan tentang otak terus dikaji sampai saat ini hingga telah memasuki babak baru yang berusaha memasukkan neurosains dalam pendidikan Islam.

Suyadi (2017a: 93) memilah landasan neurosains dalam bidang kesehatan dan pendidikan secara teologis, historis, teoritis dan akademis. Dalam landasan teologis, kata 'ubun-ubun' telah termuat dalam Alquran surat al-Alaq ayat 15-16. Selanjutnya akar kajian dalam filsafat Islam, Fiqh serta Ushul Fiqh yaitu memelihara akal menjadi landasan historis neurosains. Terakhir, neurosains secara teoretis dan akademis sangat terkait dengan konsep 'Aql dan Qolb. Oleh karena itu, dalam dunia pendidikan termasuk pendidikan Islam tidak dapat 
terlepas dari keilmuan mengenai otak karena sebagaimana David A. Sousa dalam (Suyadi, 2017b: 5) berpendapat bahwa pendidik merupakan satu-satunya pekerjaan yang setiap harinya mengubah otak walaupun ia bukan ahli mengenai otak.

Jauh sebelumnya, pada penelitian awal mengenai otak, yang dilakukan oleh Roger Sperry dan Robert Ornstein pada tahun 1960-1980, didapati gelombang-gelombang otak dan spesialisasi fungsinya. Otak bagian kanan dikenal lebih dominan pada irama, gambar, imajinasi, angan angan, warna, dimensi, sedangkan bagian kanan lebih dominan pada kata-kata, logika, angka-angka, urutan, linearitas, analisis, daftar-daftar. Penelitian awal mengenai otak tersebut diteruskan oleh Profesor Zaidel yang kemudian menemukan beberapa hasil mengejutkan yaitu mendapati bahwa pada tiap belahan otak mengandung lebih banyak kemampuan "sisi otak lainnya" dari pada yang diduga sebelumnya. Setiap belahan juga memiliki kemampuan melakukan kegiatan mental dengan jumlah yang jauh lebih stabil dan luas. Sebuah penelitian yang menyeluruh tersebut menemukan beberapa kebenaran yang begitu menarik. Seperti misalnya Einstein dan para ilmuan besar lainnya merupakan manusia yang dominan pada cortex sebelah kiri. Sementara Picasso, Cezanne dan para seniman dan musisi besar lainnya dominan pada cortex sebelah kanan (Buzan 2003, 13).

Dari sejarah penelitian mengenai otak tersebut, maka telah memberikan gambaran pada manusia bahwa perkembangan neuron atau sel saraf pada otak akan berkembang lebih banyak ketika otak digunakan. Begitu pula perkembangan otak tengah ternyata dapat memicu perkembangan otak kanan dan kiri yang dapat meningkatkan kapasitas otak secara drastis. Fungsi otak pun akan berkembang lebih dahsyat jika mengunakan kedua sisi otak secara bersamaan (Sangkanparan 2011, 17). Pasiak (2005, 166) mengungkapkan bahwa corpus callosum akan memunculkan pikiran kreatif dimana ia menghubungkan otak kiri dan kanan, juga antara otak rasional dan otak intuitif.

Buzan meyakini bahwa sekolah-sekolah telah mengajar dengan cara yang keliru. Di sekolah segala ilmu ditumpahkan dalam jumlah yang besar kepada peserta didik, namun tidak mengajarkan bagaimana mempertahankan semua ilmu itu. Cara menghafal di sekolah telah 
mendefinisikan memori secara keliru, memahaminya tidak lengkap, menerapkannya tidak tepat, dan akhirnya menyalahkannya karena gagal dan tidak dapat dinikmati. Ia mengatakan bahwa menghafal seperti ini (rote memorization) merupakan cara menanamkan kesan ke dalam otak tetapi melalui pengulangan secara paksa (Foer 2013, 10). Guilford (1974) dalam (Nursisto 1999, 32) dan disampaikan pula oleh Sudiarta $(2005,529)$ bahwa proses pembelajaran tidak hanya terbatas pada pencapaian keterampilan dasar yang biasanya didapat dari tugas rutin yang hanya bisa langsung ditemukan jawabannya melalui proses berfikir konvergen melalui hafalan dan latihan-latihan pengulangan saja, tetapi juga harus dikembangkan melalui kemampuan berpikir divergen dan kritis.

Dalam pandangan neurosains, keseimbangan antara masing-masing belahan otak juga perlu mendapat perhatian. Hal ini didasarkan karena otak kiri dan kanan selalu berusaha untuk menyeimbangkan dirinya. Bayangkan saja pada saat sesi pembelajaran, otak kiri paling dominan dari mulai mendengarkan guru, mencatat, berpikir, dan sebagainya. Sedangkan otak kanan yang cenderung untuk menyeimbangkan, ikut berinteraksi dan yang paling banyak dilakukannya adalah dengan melamun, mungkin melamun tentang film yang ia tonton sebelumnya, masa liburannya, dan sebagainya (Sutanto 2008, 15). Kejadian ini tentu tidak bisa disalahkan karena masing-masing belahan otak berusaha untuk selalu menyeimbangkan. Oleh karena itu alangkah baiknya bila kegiatan otak kanan lebih dirangsang melalui sistem pembelajaran yang lebih menyenangkan.

Proses adaptasi yang dilakukan oleh otak akan terus berlangsung secara terus menerus sehingga kreativitas akan muncul sesuai dengan pengalaman-pengalaman yang diterima oleh otak walaupun pada dasarnya tidak ada bagaian otak tertentu yang bertugas untuk berfikir kreatif, namun dengan rangsangan dan pengoptimalan fungsi otak, maka bagian-bagian pada otak akan saling berhubungan dan lebih banyak aktif sehingga menghasilkan kreativitas-kreativitas tertentu. Suyadi $(2018,171)$ mengatakan bahwa jika ditinjau dari ilmu yang mempelajari tentang otak, maka berpikir kreatif bukan merupakan tanggung jawab bagian tertentu dari otak, melainkan lebih karena rangsangan-rangsangan kreatif yang dapat mengaktifkan 
lebih banyak bagian-bagian dari otak tersebut termasuk pada bagian kognisi dan emosi.

Ketika belajar, keseluruhan bagian otak akan bereaksi, maka cara berpikir masing-masing otak tentu akan saling mendukung dalam proses pembelajaran tersebut. Misalnya otak kiri akan mengumpulkan bukti-bukti dari ucapan seorang guru dan otak kanan akan melihat seperti apa fakta-fakta itu disampaikan. Begitu pula pada otak bawah yang dikenal dengan system limbic akan mengkaji emosi yang diterima saat penyampaian fakta atau ilmu pengetahuan tersebut. Pasiak (2005, 98) mengungkapkan bahwa sistem limbic bersama dengan komponen amyglada yang terdapat pada otak memegang peranan penting dalam pengaturan emosi. Otak akan merekam kejadian melalui sirkuit khusus dalam otak dan menyimpannya sehingga ketika suatu saat si pemilik otak tersebut ingin membayangkannya maka otak akan bereaksi seperti kejadian sesungguhnya. Hukum inilah yang kemudian mendasari pekerjaan otak terutama berpikir (Pasiak 2005, 98). Oleh karena itu Chamidiyah $(2015,296)$ mengungkapkan bahwa jika perkataan digabungkan dengan musik atau gambar-gambar dan juga melibatkan emosi di dalamnya, maka perkataan tersebut menjadi lebih mudah dicerna dan diingat. Keterlibatan emosi dalam proses pendidikan sebagai sebuah pedagogi merupakan upaya membimbing anak mencapai tujuan pendidikan yang akan sangat berkaitan dengan fungsi otak. Atau dengan kata lain pengendalian dan perangsangan emosial pada peserta didik ke arah yang lebih baik merupakan tugas dari suatu proses pembelajaran.

Dengan kedahsyatan sistem kerja otak yang telah dikaruniai kepada manusia, maka sebaiknya fungsi otak hendaklah difungsikan secara optimal dari segala tipe kecerdasan. Baik diri sendiri, orang tua, guru di sekolah sebaiknya bersinergi untuk menstimulus keaktifan kinerja otak tersebut melalui berbagai cara, karena dalam pandangan kreatif, kemampuan untuk berpindah-pindah dari satu tipe kecerdasan ke tipe lainnya dapat membawa kekreatifan yang lebih dikarenakan penginderaan atau dapat dikatakan imajinasi yang berkembang pun lebih kaya (Chandra 1994, 47). Semakin banyak pengalaman, keterlibatan panca indra, imajinasi, pengetahuan, emosi yang digunakan maka akan semakin banyak dan berkembang pula sistem kerja otak dalam mewujudkan kreativitas pada diri seseorang. 
Dalam pembelajaran keagamanaan Islam seperti mata pelajaran Al-Islam dan Pendidikan Agama Islam, penggunaan imajinasi kreatif berbasis neurosains yang merupakan usaha pemaksimalan potensi akal yang ada pada masing-masing individu adalah sejalan dengan konsep keislaman. Allah menciptakan manusia sebagai makhluk paling sempurna di antara yang lainnya. Manusia diberikan akal untuk berpikir mengenai alam sekitar. Yanti $(2017,51)$ mengungkap konsep tentang akal dalam pandangan Harun Nasution bahwa akal memiliki kedudukan sangat penting, dipergunakan untuk membentuk kemakmuran dan kebaikan dalam kehidupan. Oleh karena itu penggunaan akal secara maksimal sesuai dengan tuntunan Islam merupakan keharusan sehingga umat Islam dapat menafsirkan Al-Qur'an secara rasional, tidak memandang Islam dengan sempit dan dalam penerapannya dapat memberi manfaat dan kontribusi bagi kehidupan bermasyarakat.

Ketika seseorang tidak menggunakan akal secara maksimal, maka Allah SWT akan menjadi murka, sebagaimana firmannya dalam Q.S. Yunus: 100 yang artinya: "dan tidak ada seorangpun akan beriman kecuali dengan izin Allah; dan Allah menimpakan kemurkaan kepada orang-orang yang tidak mempergunakan akalnya”. Dengan melihat akal yang harus dipergunakan secara maksimal dalam pandangan Islam dan adanya penelitian-penelitian terkini mengenai otak yang disebut neurosains, maka sesungguhnya dalam pembelajaran tentang keagamaan Islam haruslah mengarah pada pemaksimalan potensi yang telah ada yaitu otak dalam memperoleh pengetahuan tentang keislaman. Al-Raqib AL-Isfahani dalam (Pasiak 2005, 198) mengungkapkan bahwa kata akal menunjuk pada potensi dalam diri manusia untuk mendapatkan pengetahuan. Hal ini semakna dengan kemampuan berpikir atau al-quwwah al-aqilat, memahami atau alfahm, tempat berlindung atau al-malja', menahan atau mana'ah, hati atau al-qalb, dan ingatan atau dzakirah.

Suadu $(2018,85)$ mengungkapkan sedikitnya terdapat enam fungsi utama dari kemampuan otak yang sangat dibutuhkan supaya menjadi individu yang siap menghadapi perubahan yaitu ketangkasan berpikir logis, kreatif, intuitif, pengaturan emosi, motivasi dan daya tahan tubuh. Karenanya, dalam pendidikan Islam manusia wajib untuk memikirkan tujuan ia diciptakan dan segala sesuatu yang dilihat 
di sekitarnya baik kejadian maupun peristiwa. Adapun manusia yang tidak mau berpikir hanya akan mengetahuinya setelah ia mati ketika diminta pertanggungjawaban atas segala amal ibadahnya di hadapan Allah SWT dan hal tersebut tentu telah terlambat (Yahya, 2000).

Adapun kemampuan berpikir dalam diri manusia tampak berbeda-beda antara yang satu dengan yang lainnya tergantung pada masalah yang dihadapi dan bagaimana menghadapinya atau disebut sebagai kreativitas berpikir yang dalam tataran pendidikan baru merupakan level tertinggi dari konsep pembelajaran (Sousa 2012, 298). Anwar (2016, 343) mengatakan bahwa kekreatifan berpikir dilakukan berdasarkan proses keterlibatan mental seseorang dalam bertindak dan memilih yang paling baik dari berbagai pilihan berasaskan kategori tertentu. Adapun kemahiran berpikir yang dicanangkan dalam pendidikan Islam adalah bagaimana cara seseorang menuangkan ide, membuat inferens, keputusan, dan justifikasi dalam menghasilkan keputusan yang berdasarkan nilai-nilai Al-Quran dan As-Sunnah. Oleh karena itu dalam proses pembelajaran yang menginginkan pencapaian kreativitas berpikir demi penyelesaian suatu masalah, sebaiknya dilakukan melalui pemanduan terhadap apa yang dapat dilakukan oleh peserta didik (Cooper 2004, 82) sebagaimana (Buzan 2003, 137) memetakkannya seperti kegiatan pengenalan tentang diri peserta didik itu sendiri, bagaimana peserta didik tersebut belajar, berpikir, mengingat, berkreasi dan menyelesaikan masalah sendiri, dengan begitu penggunaan otak untuk berpikir dapat dimaksimalkan tidak hanya untuk menyimpan informasi dan data semata. Begitu pula dalam pengelolaan pembelajaran berbasis neurosains, khususnya pada pelajaran keagamaan Islam harus memperhatikan cara belajar, yaitu proses pembelajaran agar peserta didik tertarik, berhasil dalam belajar dengan waktu yang efisien, dan memiliki informasi/ilmu yang tersimpan dalam ingatan yang kuat (long term memory) sebagai bentuk pemaksimalan atas potensi yang telah diberikan oleh Allah SWT.

Dengan demikian potensi yang dimiliki oleh manusia sebagai anugerah dari Allah SWT tidaklah sebatas kemampuan atau intelligent tertentu saja. Namun lebih luas mencakup beberapa kecerdasan lainnya seperti IQ, EQ, SQ dan Multipe Intellegences (Suyadi 2018, 236). Tujuan yang diharapkan dapat tercapai pada pembelajaran 
keagamaan Islam sendiri tidak hanya sebatas ilmu pengetahuan yang diketahui namun juga dapat diterapkan terlebih dalam pembentukan akidah, akhlak dan ibadah dalam kehidupan sehari-hari. Atau dengan kata lain Idris (2014, 419) mengungkapkan bahwa keberadaan pendidikan Islam adalah demi pembentukan insan kamil sehingga dalam tataran operasional dan proses pembelajaran yang terjadi tidak hanya sebatas pentransferan ilmu pengetahuan, namun jauh bagaimana ilmu tersebut dapat membekas pada memori jangka panjang dan emosional peserta didik sehingga mampu membuahkan akhlak yang baik sesuai dengan pesan pada ilmu pengetahuan yang didapatinya.

\section{Imajinasi Kreatif dalam Pembelajaran Keagamaan Islam}

Vygotsky (2004, 20) berpendapat bahwa sekali sesuatu yang baru telah diciptakan atau diwujudkan secara eksternal, maka hal tersebut ada dalam kenyataan; hal tersebut memberikan sebuah bentuk materi. Artinya, imajinasi yang mengkristal inilah yang telah menjadi objek, mulai benar-benar ada di dunia nyata, untuk mempengaruhi hal-hal yang lain. Dengan cara ini, imajinasi menjadi kenyataan. Untuk itulah sekali lagi hubungan antara imajinasi kreatif dengan hasil yang akan terbentuk menjadi sesuatu yang menarik dan berkembang adalah jika seorang anak diberikan kebebebasan menggunakan otak dan imajinasinya dalam berfikir.

Sebagaimana Ribot dalam (Vygotsky 2004, 10) menyatakan bahwa setiap penemuan, baik besar atau kecil, sebelum diimplementasikan dan diwujudkan dalam kenyataan, adalah disatukan oleh imajinasi. Tidak ada yang tahu berapa banyak tindakan imajinasi yang diperlukan untuk mengubah bajak, yang dimulai sebagai sepotong kayu sederhana dengan ujung yang diasah api, dari alat manual sederhana ini, menjadi apa yang terjadi setelah serangkaian perubahan panjang yang dijelaskan dalam karya yang dikhususkan untuk benda ini. Dengan cara yang sama, api redup dari cabang kayu resin, yang merupakan obor primitif mentah pertama, melalui serangkaian penemuan panjang, telah membawa ke pencahayaan gas dan listrik. Semua objek yang digunakan dalam kehidupan sehari-hari, termasuk yang paling sederhana dan paling biasa, dapat dikatakan, hasil dari pengkristalan imajinasi. 
Banyak ilmuan-ilmuan yang temuannya justru berangkat dari imajinasi kreatif. Imajinasi kreatif tersebut lalu diturunkan ke dalam rasionalisasi. Oleh karena itu imajinasi yang semula bagi orang kebanyakan tidak rasional pada dasarnya telah menempuh beberapa tahapan yaitu imajinasi, rasionalisasi dan realisasi atau membuktikan. Inilah yang jarang sekali ditemui pada sistem logika saat ini dimana berfokus pada penemuan data-data terlebih dahulu, kemudian digeneralisir, dan diabstraksi. Sebagaimana Egan (2015, 15) mengungkapnya dalam proses pendidikan bahwa imajinasi adalah jantung dari pengalaman pendidikan yang sesungguhnya dan tidak terpisah dari "dasar-dasar" penyelidikan rasional dan merupakan pusat pragmatis keras dari semua pemikiran manusia yang efektif.

Adapun proses pendidikan Islam yang terjadi selama ini, seringkali belum diarahkan pada potensi berimajinasi yang dapat mengarahkan pada ketercapaian kompetensi pembelajaran. Padahal mata pelajaran fiqh, hadits, kalam dan tafsir sebagai inti dari materi yang harus disampaikan, saat ini tidak dapat lagi menjawab secara utuh mengenai keislaman jika hanya terpaku pada buku-buku semata (Khotimah 2014, 251). Ketika pendidikan Islam terus menjadi sorotan yang dianggap bertanggung jawab terhadap pengaruh atas perkembangan zaman (Azra 2001, 24) dimana telah berdampak pada karakter, tata nilai dan mental suatu bangsa (Sauri 2010, 1), walaupun tidak dapat dibenarkan sepenuhnya, maka pendidikan Islam harus bangun dan merekonstruksi diri. Begitu pula ketika umat Islam telah berazam untuk berusaha bangkit dari keterpurukan pendidikan Islam setelah menyadari dampak dari penetrasi Barat terhadap dunia Islam semenjak abad ke 18 (Fazlurrahman 2018, 74), maka proses pendidikan Islam adalah pembentukan manusia menjadi seorang yang memiliki kemampuan dalam pengembangan diri serta pembangunan masyarakat, alam sekitar dan negara (Anwar 2016, 349). Untuk itulah, pemahaman keagamaan Islam kemudian tidak cukup hanya sebatas teori dan tidak pada pengembangan potensi atau fitrah yang telah ada yang dapat membangkitkan kreativitaskreativitas dan kemandirian berasaskan Al-quran dan As-sunnah di masa mendatang.

Runco \& Johnson $(2002,429)$ menemukan bahwa sebagian besar, guru dan orang tua di Amerika Serikat melihat sifat kreatif 
pada anak-anak. Orang tua dan guru sepakat bahwa anak-anak kreatif akan cenderung mudah beradaptasi, suka berpetualang, pintar, ingin tahu, berani, memiliki tujuan hidup, imajinatif, dan berdaya cipta. Fakta yang ditemukan pada penelitian yang dilakukan oleh Lake Research Partners (The Imagine Nation, 2008) adalah hampir 9 dari 10 responden (89\%) melaporkan bahwa penggunaan pemikiran imajinatif penting bagi inovasi dan keberhasilan seseorang dalam ekonomi global di abad ke-21.

Dalam beberapa tahun terakhir, telah dilakukan penelitian bahwa imajinasi sangat berperan dalam berbagai bidang atau subjek pendidikan (Jagla 1994, 10), (Davey 2009, 124), dan (Judson 2014, 4). Oleh karena itu, imajasi kreatif berbasis neurosains merupakan salah satu metode yang dapat digunakan dalam pembelajaran keagamaan Islam. Seorang pendidik dapat mengajak peserta didik untuk mengembangkan imajinasi kreatifnya melalui berbagai rangsangan-rangsangan pembelajaran seperti lagu dan musik dalam kegiatan menulis di kelas (Trimantara 2005, 3), gambargambar (Chamidiyah 2015, 296), permainan (Moller, 2015), (Holis 2016, 34-35), (Hatt 2018, 130-131), (Vygotsky 2004, 17) dan sebagainya.

Imajinasi dalam pendidikan memiliki hubungan yang saling mendukung dengan pengertian kreativitas. Kata kreatif dari kreativitas yang merupakan sebuah kemampuan dalam memunculkan kebaharuan atau keberbedaan dari sebelumnya merupakan bentukan dari rangsangan-rangsangan imajinasi seseorang. Sebagai contoh sederhana, rangsangan imajinasi seorang anak dalam menulis dapat diberikan melalui musik. Lagu atau musik digunakan sebagai pencipta suasana yang mensugestikan, menstimulus, dan menjadi jembatan dalam membayangkan, membuat gambar serta urutan kejadian berdasarkan tema yang ada pada musik tersebut. Kemampuan merespon dari hasil imajinasi tersebutlah kemudian dengan logika akan diungkapkan kembali ke dalam bentuk tulisantulisan (Trimantara 2005, 3). Oleh karena itu dapat dikatakan seni merupakan bagian dari rangsangan atas pemunculan imajinasi itu sendiri.

Sousa (2011, 41-42) mengungkapkan bahwa seni dapat mengembangkan fungsi otak. Studi penelitian telah mengungkapkan 
paparan terhadap seni yaitu dapat meningkatkan perhatian, keterampilan spasial, dan kreativitas seseorang. Ia juga menyayangkan kalau seni seringkali terkesampingkan di sekolah padahal penelitian tentang otak telah menunjukkan bahwa seni adalah kontributor penting untuk pengembangan proses kognitif. Sousa dalam (Suyadi 2018 , 33) menyatakan dalam pembelajaran otak melibatkan berbagai jaringan dalam otak. Seni visual seperti melukis, menggambar dan mewarnai diporses pada lobus oksipital dan lobus temporal. Seni literatur seperti bernyanyi, prosa, puisi, dan sejenisnya diproses di bagian broka dan area wernicke. Seni gerak seperti menari, olahraga dan sejenisnya diproses pada bagian korteks motorik, terutama pita tipis yang melintasi bagian atas otak. Seni musik diproses di korteks pendengaran, terutama lobus temporal.

Selanjutnya suatu bentuk rangsangan lainnya yang dapat mengaktifkan imajinasi dan sistem kerja otak adalah melalui permainan. Audrey Curtis (1988) mengungkapkan dengan bermain kreatif, perkembangan dan pengintegrasian kemampuan yang dimiliki akan didapatkan oleh seorang anak (Holis 2016, 34-35). Rogers pada 1959 juga mengemukakan bahwa karakteristik dominan dari pikiran kreatif adalah kemampuan untuk memvisualisasikan alternatif terhadap apa yang ada atau bermain dengan rasa ingin tahu atau denga konsep yang diluar pemikiran orang lain. Anak-anak kecil sangat mudah berimajinasi dan berbakat dalam bermain-main dengan objek, ide, atau kepribadian. Tidak ada sensor untuk mereka, tidak ada kendala; mereka hanya bermain dengan kemungkinan atau potensi (Hatt 2018, 130-131). Proses penggunaan imajinasi pada anak tervisualisasikan dari permainan-permainan yang ia mainkan. Kebebasan berekspresi pun didapatkan oleh anak-anak melalui permainan tersebut. Sehingga tak jarang kita dapatkan dunia anakanak sebagai dunia fantasi yang terkadang sulit dicerna oleh orang dewasa. Namun sesungguhnya keadaan pengembangan imajinasi yang terjadi semenjak kecil tersebut dapat membawa anak-anak pada kreativitas-kreativitas yang membebaskan pikiran mereka untuk berpikir dan menyelesaikan masalah di masa mendatang. Oleh karena itu, Bronowski $(2015,26)$ mengungkapkan bahwa jika ilmu pengetahuan dapat dimunculkan dari imajinasi, dan jika pengalaman-pengalaman dapat diperoleh dari kegiatan bermain, maka penyampaian ilmu pengetahuan sebaiknya tidak monoton. 
Proses berpikir yang terbebaskan akan mucul dari imajinasi yang ada dalam otak manusia. Ketika seorang anak diberikan suatu pengalaman dalam proses belajar atau bahkan kegiatan bermain sekalipun, maka akan terjadi dua proses ketergantungan yang saling menguntungkan. Melalui bermain, anak-anak menciptakan situasi imajiner, membuat dan mengikuti aturan khusus, dan memerankan peran-peran tersebut dengan tepat. Misalnya, bermain peran dengan berpura-pura menjadi petugas kebersihan, ada kostum khusus, peralatan dan bahasa yang akan digunakan. Bermain memungkinkan anak-anak untuk mempraktekkan pengaturan diri, memisahkan pikiran dari tindakan, dan dengan sengaja memperhatikan stimulasi spesifik. Vygotsky berpendapat bahwa ada dua pengalaman yang terjadi pada saat bermain "there is a double, mutual dependence between imagination and experience. If, in the first case, imagination is based on experience" (Vygotsky 2004, 17). Ketika pengalamanpengalaman digabungkan dengan cara-cara baru, maka akan sangat mungkin untuk menghasilkan ciptaan baru. Atau pada sisi lain juga akan memungkinkan seseorang untuk membawa kepada penciptaan imajinasi dari hal-hal yang didengar dan tidak terlihat.

Astuti $(2011,56)$ mengungkapkan bahwa pendidikan seni merupakan salah satu bentuk media yang bisa mengembangkan mental anak karena dapat mempengaruhi perkembangan emosi, spiritual, kebudayaan, pola pikir serta pola kerja. Sebuah penelitian yang dilakukan oleh beberapa peneliti di Southern Federal University, Rostov-on-Don, Russia juga telah membuktikan bahwa dilihat dari karakter psikolog, seorang yang berkecimpung dalam bidang seni lebih cenderung memiliki imajinasi kreatif yang sangat produktif. Mereka mencirikan sikap imajinasi kreatif yang produktif tersebut dengan sikap yang stabil, relax, kepuasan terhadap diri, flexible, cerdik, serta ketenangan emosi (Dikiy, Dikaya, Karpova, Lavreshina, \& Kagramanyan, 2018). Vygotsky sendiri telah menyambut pendekatan psikoanalisis bahwa seni adalah pelepasan sosial dari ketidaksadaran atau pembebasan emosi. Ia juga mendukung teori katarsis yang menyatakan bahwa orang-orang dibebaskan melalui ledakan emosi, yang membuat imajinasi berkembang karena menafsirkan emosiemosi tersebut (Lindqvist 2003, 247). 
Berkaitan dengan emosi, seorang guru juga dapat melakukan proses pembelajaran dengan menggunakan seni berkomunikasi yang di sebut hypnoteaching di kelas. Hypnoteaching ini dimaksudkan untuk memberi sugesti kepada peserta didik agar lebih cerdas. Hypnoteaching atau seni berkomunikasi dapat diberikan menggunakan kata-kata positif dalam penyajian materi pelajaran dengan menggunakan sugesti alam bawah sadar dan juga imajinasi peserta didik saat sedang belajar. Kemampuan sugesti akan melekat pada otak dan menghantarkannya pada apa yang dipikirkannya (Wijaya 2018, 15-16). Dengan kata lain, sugesti akan mengantar pada apa yang dipikirkan atau apa yang dibayangkan. Untuk itulah peran imajinasi jelas memberikan kesempatan kepada peserta didik untuk membayangkan sesuatu terlebih dahulu kemudian baru melakukannya.

Hanafi $(2016,33)$ menambahkan dalam kreativitas terdapat sebuah kegiatan untuk memikirkan dan memproses suatu masalah melalui proses yang dapat dikatakan unik dan berbeda dari biasanya, seperti yang diungkapkan oleh Wallas (Barrett 2001, 26) bahwa dalam pencapaian solusi tersebut, kreativitas terkadang malah harus bertempur di dalam alam bawah sadar yang sangat dalam. Selama periode tersebut, pikiran akan menginkubasi ide dan mempersiapkannya kemudian. Perilaku-perilaku kreatif akan tampak bersama dengan unsur-unsur dasar yang menjadi faktor penentu pembentukan kreatififas itu sendiri yaitu kemampuan berimajinasi, kapisitas memori/pengetahuan, logika akal sehat, dan keterampilan motorik (Muliawan 2016, 21). Keempat unsur dasar ini akan saling terkait sesuai dengan porsi penggunaannya masing-masing, namun penggunaan imajinasi yang dalam hal ini juga merupakan proses pemaksimalan fungsi otak, memegang porsi yang paling besar dalam pembentukan kreativitas. Hal ini dikarenakan melalui imajinasi, seseorang akan mampu merambah sesuatu yang sama sekali belum pernah ada menjadi ada.

Keempat tahap kreativitas yang diuraikan oleh Wallas tersebut adalah 1) Persiapan, yaitu mempelajari sebuah objek secara rasional dan linier, 2) Inkubasi, yaitu mengambil jarak dengan masalah dan mengendapnya sementara, 3) Iluminasi, yaitu mengambil suasana rilex sementara seperti berjalan-jalan di pinggir pantai, menikmati 
segelas kopi dan sebagainya, 4) verifikasi, yaitu menguji kesesuaian jawaban intuitif pada masalah utama (Pasiak 2005, 160). Untuk itulah, dalam hal ini otak memiliki peranan yang luar biasa dalam perkembangan kreativitas seseorang dimana juga merupakan tempat terjadinya perkembangan kognitif seseorang.

Lindqvist (2003, 247) menjelaskan bahwa imajinasi melibatkan ekspresi sentral dari reaksi emosional. Seperti pada permainan anak-anak, mereka dapat mengendalikan tindakan dan gerakan mereka (reaksi estetik) yang meningkatkan pengalaman dan intensitas tindakannya. Anak-anak membebaskan emosi mereka melalui imajinasi mereka. Dengan demikian, mereka menciptakan interpretasi mereka sendiri tentang apa yang telah mereka alami, dengan cara yang mirip ketika seorang penulis menciptakan karyanya dan seorang pembaca menciptakan interpretasinya terhadap karya tersebut. Dengan kata lain proses pembelajaran hendaklah memperlakukan peserta didik bukan hanya seperti kotak penyimpanan. Namun diperlukan konstruksi ilmu pengetahuan dan penciptaan iklim motivasional yang benar untuk belajar (Setyawan, 2006).

Terkait dengan perspektif tersebut, Ogunnaike (2015, 11-12). merumuskan beberapa gambaran umum tentang ide-ide konstruktif yang diungkapkan oleh Vygotsky dengan Garner, yaitu:

a. Anak adalah "protagonis" pada dunia pembelajaran. Anak menciptakan, membangun, menemukan, dan memutuskan "apa" dan "bagaimana" dari perjalanan belajarnya.

b. Sebagai protagonis, anak secara aktif membangun pengetahuan melalui interaksi yang bermakna dengan lingkungan belajar. Interaksi ini terjadi sebagian besar melalui permainan.

c. Pembelajaran adalah holistik dan hierarkis ketika bergerak dari kerangka konkret, sederhana, khusus-ke-khusus penalaran ke frame yang lebih abstrak, fleksibel, dan kurang gosentris.

d. Lingkungan belajar adalah lingkungan yang sengaja disiapkan dan menyediakan sumber daya konkret yang mempromosikan eksplorasi langsung, pemecahan masalah, perilaku pro-sosial, hubungan sosio-emosional, 
dan pengalaman yang menantang anak-anak muda untuk berpikir di luar "diri" langsung mereka atau/ dan lingkungan.

e. Kehadiran orang dewasa yang peduli yang memodelkan perilaku pro-sosial dan etis dan juga memberikan tanggapan kepada setiap ide, saran, dan perspektif anak adalah penting.

Sousa (2012, 103) mencontohkan pada pembelajaran tentang sejarah Perang Sipil Amerika Serikat, peserta didik bernyanyi tentang materi yang dibuat menjadi lagu, membaca puisi, menulis, menampilkan sketsa serta membuat lukisan yang menggambarkan panorama perang yang terjadi pada saat kejadian itu. Dengan cara tersebut, maka didapati lebih banyak peserta didik yang masih dapat mengingat sebab dan akibat dari perang tersebut sampai beberapa tahun ke depan dari kehidupan mereka. Kieran Egan juga meyakini bahwa kekuatan dari citra mental yang ditimbulkan dari kegiatankegiatan pembelajaran dengan menggunakan imajinasi kreatif tersebut adalah sebagai cara yang efektif dalam menyampaikan makna bagi peserta didik. Hal ini disebabkan oleh karena gambaran yang didapatkan dalam setiap pengalaman yang dihasilkan, walaupun kecil, dapat menjalin materi pembelajaran dengan emosi (Judson 2014, 5).

Selain dari pada unik dan menyenangkan, pembelajaran yang melibatkan imajinasi kreatif juga telah memecahkan paradigma bahwa sekolah itu membosankan dan melelahkan. Dalam penelitian yang dilakukan oleh Gallup (Sousa 2012, 41) menyatakan dari 800 peserta didik usia 13-17 tahun telah memilih jawaban bahwa sekolah adalah tempat yang membosankan (50\%) dan melelahkan (42\%). Bagaimana tidak, pembelajaran yang berlangsung sampai berjam-jam di sekolah tidak lebih dari kegitan masuk ke dalam kelas, duduk rapi, mendengarkan materi dan ironisnya tidak satupun materi yang dapat mereka tangkap secara maksimal (Muali 2016, p. 11)

Seperti yang telah diuraikan sebelumnya bahwa keunikan proses perkembangan imajinasi yang dapat dirangsang melalui seni, pergerakan, permainan, dan emosi adalah bagian dari rangsangan kognitif bagi peserta didik. Oleh karena itu proses pembelajaran keagamaan Islam dapat dikondisikan dengan berbagai macam 
kegiatan pengembangan imajinasi kreatif atau dengan kata lain Yusmaliana $(2019,50)$ menyatakannya dengan bentuk pendidikan yang lebih menginspirasi, mencerahkan dan membangun nilai-nilai Islam. Berbagai hal yang dapat dilakukan adalah seperti misalnya mengenal huruf hijaiyah melalui permainan (Muhaningsih, Fadillah, \& Purwati, 2017), menghafal doa melalui musik (Chakim, 2018), melakukan drama tentang sejarah peperangan Islam, memberikan cerita yang menarik dan berhubungan dengan nilai-nilai keislaman atau pengembangan proses-proses pembelajaran lainnya. Peserta didik akan lebih banyak mengingat isi pembelajaran ketika berhubungan dengan emosional. Karenanya, seorang pendidik sudah seharusnya selalu melibatkan secara emosional pada konten pembelajaran agar dapat memicu imajinasi kreatif peserta didik. Sebagaimana Egan (2015) yang selalu mempertegas bahwa merangsang imajinasi bukanlah kegiatan pendidikan alternatif untuk diperdebatkan, namun merupakan prasyarat untuk membuat kegiatan apa pun menjadi edukatif.

\section{Simpulan}

Pengembangan imajinasi kreatif peserta didik berbasis neurosain dalam proses pembelajaran keagamaan Islam merupakan salah satu langkah bagi pengembangan potensi yang ada pada manusia yang dalam hal ini adalah peserta didik. Berfungsinya imajinasi kreatif adalah tergantung pada serangkaian faktor yang sangat beragam dimana pada masa anak-anak imajinasi kreatif beroperasi dengan cara tertentu, yang merupakan karakteristik dari tahap tertentu dari perkembangan anak yaitu pada pengalaman dan stimulasi atau rangsangan yang diterima. Pentingnya imajinasi kreatif dalam kehidupan telah diungkapkan oleh beberapa ilmuan terdahulu yang menghasilkan inovasi-inovasi besar setelahnya. Oleh karena itu, dalam pembelajaran keagaman Islam yang memiliki tujuan membentuk insan kamil yang memiliki keseimbangan antara aspek kognitif, afektif dan psikomotorik, serta secara psikologisnya dapat mengoptimalkan potensi manusia yang merupakan fitrah manusia, tidaklah cukup kalau hanya sebatas pada teori semata, namun lebih pada proses membangkitkan kreativitas-kreativitas dan kemandirian berasaskan Al-quran dan As-sunnah demi kehidupan yang lebih bermakna dan bermanfaat di masa mendatang. 
Adapun berbagai kegiatan-kegiatan pembelajaran keagama Islam yang dapat menstimulasi imajinasi kreatif anak dapat dilakukan seperti bermain musik religi, pembacaan kisah-kisah agung, nyanyian-nyanyian spiritual, tarian-tarian estetik, lukisan-lukisan unik, dan lain-lain sebagainya yang dapat membangkitkan nilai-nilai yang terkandung di dalam pembelajaran tersebut dan tersimpan dalam memori jangka panjang sehingga menghasilkan kreativitas dan kebermanfaatan dimasa mendatang dimana proses imajinasi kreatif tersebut akan diinkubasi sehingga pada saatnya nanti dapat dirasionalkan dan direalisasikan dalam bentuk inovasi-inovasi. 


\section{DAFTAR PUSTAKA}

Anwar, B. (2016). Pendidikan Islam Melalui Kemahiran Berfikir Membentuk Moral dan Akhlakul Karimah Pelajar Islam. AlDaulah, 5(2), 341-351.

Aschoeke, Tbittlin, LanguageGame, Itiaden, Pbenner, Mheimann, ... Ekrueger. (2006). Cognitive Psychology and Cognitive Neuroscience. Image (Rochester, N.Y.), 39(3), 200-210.

Astuti, F. (2011). Menggali dan Mengembangkan Potensi Kreativitas Seni pada Anak Usia Dini. Jurnal Bahasa Dan Seni, 14 No. 2, 52-63.

Atkinson, R. L., Atkinson, R. C., \& Hilgard, E. (2011). Pengantar Psikologi. Jakarta: Erlangga.

Azra, A. (2001). Pendidikan Akhlak dan Budi Pekerti 'Membangun Kembali Anak Bangsa”' Mimbar Pendidikan, 1(XX).

Barrett, F. D. (2001). Creativity Techniques: Yesterday, Today, and Tomorrow. S.A.M. Advanced Management Journal, 25-35.

Bronowski, J., Commager, H. S., Allport, G. W., \& Buck, P. H. (2015). Imagination and the University. Canada: Toronto Press. https://doi.org/10.3138/j.ctt15jjfh0.8

Buzan, T. (2003). Use Both Sides of Your Brain: Teknik Pemetaan Kecerdasan dan Kreativitas Pikiran, Temuan Terkini tentang Otak Manusia. Yogyakarta: Ikon Teralitera.

Chakim, L. (2018). Efektifitas Pembelajaran Menghafal Doa dengan Menggunakan Musik di MIN Ngronggot Kabupaten Nganjuk. Jurnal Pendidikan Islam, 8(1).

Chamidiyah, C. (2015). Pembelajaran Melalui Brain Based Learning dalam Pendidikan Anak Usia Dini. Edukasia: Jurnal Penelitian Pendidikan Islam, 10(2). https://doi.org/10.21043/ EDUKASIA.V10I2.795

Chandra, J. (1994). Kreativitas: Bagaimana Menanam, Membangun, dan Mengembangkannya. Yogyakarta: Kanisius. 
Cooper, C. (2004). 'A struggle well worth having': the uses of theatrein-education ( TIE ) for learning. Support for Learning, 19(2), $81-88$.

Davey, T. (2009). Book Riview: Teaching and Learning Outside the Box: Inspiring Imagination Across the Curriculum. Catholic Education: A Journal of Inquiry and Practice, 13(1).

Dikiy, I. S., Dikaya, L. A., Karpova, V. V, Lavreshina, A. Y., \& Kagramanyan, M. R. (2018). Psychological characteristics of art specialists with a highly productive creative imagination. Psychology in Russia: State of the Art, 11(2). https://doi. org/10.11621/pir.2018.02010

Egan, K. (2004). Memory, Imagination, and Learning: Connected by the Story. Phi Delta Kappan, 70(6).

Egan, K., \& Judson, G. (2016). Imagination and the Engaged Learner: Cognitive Tools for The Classroom. Canada: Howker Brownlow Education.

Egan, K., Stout, M., \& Takaya, K. (2007). Teaching and Learning Outside the Box. New York: Teachers College Press.

Faisal, A. (2015). Think Like A Millionaire. jakarta: Prima Ufuk Semesta.

Fazlurrahman, M. (2018). Modernisasi Pendidikan Islam: Gagasan Alternatif Fazlur Rahman. TA'LIM: Jurnal Studi Pendidikan Islam, 1(1), 73-89.

Fleer, M. (2012). Imagination, emotions and scientific thinking: What matters in the being and becoming of a teacher of elementary science? Cultural Studies of Science Education, 7(1), 31-39. https://doi.org/10.1007/s11422-011-9365-z

Foer, J. (2013). Moonwalking with Einstein: Rahasia Memiliki Ingatan Super. Jakarta: PT Gramedia Pustaka Utama.

Goodreads. (n.d.). Quotable Quote. Retrieved from https://www. goodreads.com/quotes/556030-imagination-is-moreimportant-than-knowledge-for-knowledge-is-limited, diakses tanggal 12 Oktober 2018

Hanafi, I. (2016). Neurosains-spiritualitas dan pengembangan potensi kreatif. An-Nuha, 3(1), 23-38. 
Hatt, B. E. (2018). The new ICE-Age: Frozen and Thawing perceptions of imagination. Canadian Journal of Education, 41(1), 124-147.

Holis, A. (2016). Belajar Melalui Bermain untuk Pengembangan Kreativitas dan Kognitif Anak Usia Dini. Jurnal Pendidikan Universitas Garut, 09(01), 23-37.

Idris, M. (2014). Konsep Pendidikan Humanis dalam Pengembangan Pendidikan Islam. Miqot, XXXVIII(2), 417-434.

Jagla, V. M. (1994). Teachers Everyday Use of Imagination and Intuition In Pursuit of the Elusive Image. Albany: State University of New York Press. Retrieved from https:// web-b-ebscohost-com.ezproxy.scottsdalecc.edu/ehost/ ebookviewer/ebook?sid=fc1 19726-2121-4c5f-a5d537608817 alb0\%40pdc-v-sessmgr06\&vid $=0 \&$ format $=E B$

Judson, G. (2014). The Role of Mental Imagery in Imaginative and Ecological Teaching. Canadian Journal of Education, 37(4).

Judson, G. (2016). Two Key Points for Understanding Imagination in Education. Retrieved November 27, 2018, from https://www.gettingsmart.com/2016/09/imaginationmisunderstood/?utm_campaign $=$ coschedule \&utm source $=$ twitter \&utm_medium $=$ Getting_Smart\&utm content=Two Key Points for Understanding Imagination in Education

Khotimah. (2014). Pemikiran Fazlur Rahman Tentang Pendidikan Islam. Jurnal Ushuluddin, 22(2), 239-253. Retrieved from http://ejournal.uin-suska.ac.id/index.php/ushuludin/ article/view/739\%5Cnhttp://ejournal.uin-suska.ac.id/ index.php/ushuludin/article/download/739/690

Lindqvist, G. (2003). Vygotsky's Theory of Creativity. Creativity Research Journal, 15(2-3), 245-251. https://doi.org/10.108 $0 / 10400419.2003 .9651416$

Moller, S. J. (2015). Imagination, Playfulness, and Creativity in Children's Play with Different Toys. American Journal of Play, $7(3)$. 
Muali, C. (2016). Konstruksi Strategi Pembelajaran Berbasis Multiple Intelligences Sebagai Upaya Pemecahan Masalah Belajar. Pedagogik; Jurnal Pendidikan, 3(2), 1-12.

Muhaningsih, R., Fadillah, \& Purwati. (2017). Peningkatan Pengenalan Huruf Hijaiyah Melalui Bermain pada Anak Usia 4-5 Tahun. Jurnal Pendidikan Dan Pembelajaran, 6(5).

Muliawan, J. U. (2016). Mengembangkan Imajinasi dan Kreativitas Anak (I). Yogyakarta: Gava Media.

Murrel, K. (2001). Book review: Appreciative inquiry: Change at the speed of imagination. Organization Development Journal, 19(3), 92-93.

New Poll Reveals Stifling Imagination in Schools Underlies Innovation and Skills Deficit. (2008). Retrieved March 27, 2019, from https://www.namm.org/news/press-releases/ new-poll-reveals-stifling-imagination-schools-unde

Nursisto. (1999). Kiat Menggali Kreativitas. Yogyakarta: PT. Mitra Gama Widya.

Ogunnaike, Y. A. (2015). Early Childhood Education and Human Factor: Connecting Theories and Perspectives. Early Childhood Education Journal, 21(1), 9-26.

Pasiak, T. (2005). Revolusi IQ/EQ/SQ: Antara Neurosains dan AlQuran (V). Bandung: Mizan.

Runco, M. A., \& Johnson, D. J. (2002). Parents' and Teachers' Implicit Theories of Children's Creativity : A Cross-Cultural Perspective. Creativity Research Journal, 14, 427-438.

Sangkanparan, H. (2011). Dahsyatnya Otak Tengah: Jadikan Anak Anda Cerdas Saat Ini Juga. Jakarta: VisiMedia.

Sauri, S. (2010). Membangun karakter bangsa melalui pembinaan profesionalisme guru berbasis pendidikan nilai. Jurnal Pendidikan Karakter, 2(2), 1-16.

Setyawan, I. (2006). Pembelajaran Pendidikan Tinggi dan Pengembangan Kreativitas. Jurnal Psikologi Universitas Diponegoro, 3(2). 
Sousa, D. A. (2011). Commentary Mind, Brain, and Education: The Impact of Educational Neuroscience on the Science of Teaching. Learning Landscapes, 5(1), 37-43.

Sousa, D. A. (2012). Bagaimana Otak Belajar: Edisi Keempat. Jakarta: Tim Indeks.

Suadu, F. (2018). Manusia Unggul Neurosains dan Al-quran. Jakarta: PT. Penjuru Ilmu Sejati.

Sudiarta, I. G. P. (2005). Pengembangan Kompetensi Berpikir Divergen dan Kritis Melalui Pemecahan Masalah Matematika Open-Ended. Jurnal Pendidikan Dan Pengajaran IKIP Negeri Singaraja, (3 Th. XXXVIII).

Sutanto, W. (2008). Brain Management Series for Learning Strategy: Be an Absolute Genius! Jakarta: PT. Elex Media Komputindo.

Suyadi. (2012). Integrasi Pendidikan Islam dan Neurosains dan Implikasinya bagi Pendidikan Dasar (PGMI). Al-Bidayah, 4(1), 111-130.

Suyadi. (2017a). Pendidikan Islam Dan Neurosains. In Prosiding Konferensi Nasional Ke-6 Asosiasi Program Pascasarjana Perguruan Tinggi Muhammadiyah 'Aisyiyah (APPPTMA) (pp. 93-107).

Suyadi. (2017b). Teori Pembelajaran Anak Usia Dini Dalam Kajian Neurosains. Bandung: PT. Remaja Rosdakarya.

Suyadi. (2018a). Pendidikan Islam Anak Usia Dini Dalam Perspektif Neurosains: Robotik Akademik dan Saintifik. Edukasia: Jurnal Penelitian Pendidikan Islam, 13(2), 231-262.

Suyadi. (2018b). The Synergy of Arts, Neuroscience, and Islam in Early Childhood Learning in Yogyakarta. TARBIYA: Journal of Education in Muslim Society, 5(1), 30-42.

Taufiq, A., Prianto, P. lestari, \& Mikarsa, H. L. (2014). Modul: Hakikat Pendidikan di Sekolah Dasar. Retrieved November 27, 2018, from http://repository.ut.ac.id/4122/1/PDGK4403-M1. pdf

Trimantara, P. (2005). Metode Sugesti-Imajinasi dalam Pembelajaran Menulis dengan Media Lagu. Jurnal Pendidikan Penabur, 05(04), 1-14. 
Tsai, K. C. (2012). Play, Imagination, and Creativity: A Brief Literature Review. Journal of Education and Learning, 1(2), 15-20. https://doi.org/10.5539/jel.v1n2p15

Vygotsky, L. S. (2004). Imagination and Creativity in Childhood. Journal of Russian and East European Psychology, 42(1), 7-97. https://doi.org/10.2753/RPO1061-0405290173

Wijaya, H. (2018). Pendidikan Neurosains Dan Implikasinya Dalam Pendidikan Masa Kini. Retrieved from https://www. researchgate.net/publication/323114055_Pendidikan_ Neurosains_Dan_Implikasinya_Dalam_Pendidikan_Masa_ Kini diakses tanggal 21 Oktober 2018

Yahya, H. (2000). Bagaimana seorang Muslim berpikir ? London: TaHa Publishers Ltd.

Yanti, D. (2017). Konsep Akal dalam Perspektif Harun Nasution. Intelektualita, 06(01), 51-62. https://doi.org/https://doi. org/10.19109/intelektualita.v6i1.1300

Yusmaliana, D., \& Widodo, H. (2019). Reconstruction Of Islamic Education Curriculum In The Disruption. IJISH (International Journal of Islamic Studies and Humanities), 2(1). 
Desfa Yusmaliana dan Suyadi 